\title{
PRASASTI PLUMPUNGAN SEBAGAI IKON BATIK KOTA SALATIGA SERTA DAMPAKNYA BAGI PENINGKATAN EKONOMI DAN PARIWISATA
}

\author{
Oleh : \\ Ken Widyatwati \\ Fakultas Ilmu Budaya
}

\begin{abstract}
Javanese society still steeped in culture and mystique there are a lot of myths, one of hich is the myths associated with the presence of legends inscriptions .

Inscription Plumpungan and Plumpungan which is the origin story of Salatiga. Salatiga community later made into an icon inscription plumpungan the name of Batik Plumpungan. Plumpungan batik is batik drawing pattern is a form of inscription Plumpungan. As one of cultural studies, this research is very important because Inscription Plumpungan used as an icon with the name of Salatiga batik "Batik Plumpungan". Legends and inscriptions Plumpungan in Salatiga a local cultural heritage that should be preserved and conserved as an effort to increase the cultural richness of Indonesia. The existence of legends and inscription Plumpungan used as a traditional batik icon Salatiga have an impact for the improvement of people's income Salatiga and also support an increase in the arrival of tourists both local, domestic and foreign so salatiga tourism sector in the city has increased.

Small industrial centers established Batik Plumpungan together in one container that Joint Business Group. Joint Business Group is a group of batik artisans who make batik and obtain capital loans to both individuals and groups. In addition to their capital loan craftsmen also have no trouble selling the results because the centers adannya Batik buyers usually consists of tourists, both domestic, local directly come to the center of batik.
\end{abstract}

Keyword: Legend,Inscription,Icon,Batik Plumpungan

\section{LATAR BELAKANG}

Indonesia terdiri atas beribu-ribu pulau yang terdiri dari beraneka ragam suku bangsa dan kebudayaan. Setiap suku bangsa di Indonesia menciptakan, menyebarluaskan dan mewariskan kebudayaan masing-masing dari satu generasi ke generasi berikutnya. Keanekaragaman suku bangsa dan kebudayaan itu pada hakikatnya adalah satu dan memberi identitas khusus serta menjadi modal dasar pengembangan budaya bangsa.
Keanekaragaman kebudayaan pada setiap suku bangsa di indonesia menunjukkan kekayaan kebudayaan Nusantara. Masing-masing daerah di Indonasia memiliki corak kebudayaan yang berbeda-beda. Untuk mengembangkan kebudayaan daerah yang merupakan akar dari kebudayaan nasional, Pemerintah memberikan landasan seperti yang tercantum dalam UUD 1945 pasal 32 yang berbunyi "Pemerintah memajukan Kebudayaan Nasional Indonesia”. 
HUMANIKA Vol. 21 No. 1 (2015) ISSN 1412-9418

Kebudayaan daerah adalah akar dari kebudayaan nasional. Oleh karena itu kebudayaan daerah harus dilestarikan dan dipertahankan. Salah satu usaha untuk mempertahankan kebudayaan daerah adalah melalui pelestarian folklor. Folklor sebagai sumber informasi kebudayaan daerah tidak bisa diabaikan dalam usaha menggali nilai - nilai dan keyakinan yang tumbuh dalam suatu masyarakat.Danandjaja mendefinisikan folklor sebagian kebudayaan suatu kolektif yang tersebar dan diwariskan turun-temurun, diantara kolektif macam apa saja, secara tradisional dalam versi berbeda,baik dalam bentuk lisan maupun contoh yang disertai dengan gerak isyarat atau alat bantu pengingat.Sementara itu,John Harold Bruvant menggolongkan folklor dalam tiga kelompok yaitu: (a) folklor lisan, (b) folklor sebagian lisan,(c) folklor bukan lisan.

Legenda bagian dari merupakan folklor lisan. Legenda adalah cerita prosa rakyat yang dianggap oleh yang empunya cerita sebagai suatu kejadian yang sungguh-sungguh pernah terjadi karena terdapat peninggalan tentang legenda tersebut ( Danandjaja, 1997:66). Bruvand menggolongkan legenda menjadi empat kelompok yaitu: (a) legenda keagamaan, (b) legenda alam gaib, (c) Legenda perseorangan dan d4) legenda setempat, legenda prasasti plumpungan termasuk legenda setempat karena berhubungan dengan asal-usul terjadinya Kota Salatiga.

\section{RUMUSAN MASALAH}

Berdasarkan latar belakang di atas, maka rumusan masalah dalam penelitian ini adalah sebagai berikut : Apa latar belakang legenda Prasasti Plumpungan dijadikan ikon Batik Kota Salatiga dan bagaimana dampaknya bagi peningkatan pendapatan dan pariwisata di Kota Salatiga.

\section{TUJUAN PENELITIAN}

Berdasarkan kepada rumusan masalah di atas, maka tujuan penelitian ini adalah sebagai berikut: mengungkap asalusul legenda Prasasti Plumpungan dan latar belakang prasasti Plumpungan dijadikan sebagai ikon batik Kota Salatiga.

Penelitian ini juga mengungkapkan dan menjelaskan dampak dari batik Plumpungan sebagai ikon batik khas Kota Salatiga bagi peningkatan pendapatan dan peningkatan sektor pariwisata di Kota Salatiga.

\section{LANDASAN TEORI}

\section{Teori Folklor}

Folklor secara etimologis terdiri dari dua kata dasar yaitu Folk dan lore. Folklor merupakan pengindonesiaan kata dalam bahasa Inggris Folklor. Menurut Alan Dundes dalam Danandjaya 1997 : 1) folk merupakan istilah kolektif yaitu sekolompok orang yang memiliki ciri-ciri pengenal fisik sosial dan kebudayaan, sehingga dapat dibedakan dari kelompokkelompok sosial lainnya. Namun, yang penting adalah bahwa kolektif itu memiliki suatu trsdisi yaiyu kebudayaan yang merupakan warisan dari generasi sebelumnya, atau sedikitnya dua generasi yang diakui sebagai pemelik bersama.

Sedangkan lore adalah tradisi folk yaitu sebagaimana kebudayaan yang diwariskan turun-temurun secara lisan atau melalui suatu contoh yang disertai dengan gerak isyarat atau alat pembantu pengingat (Danandjaja 1997 : 1-2) dengan kata lain lore adalah suatu tradisi kebudayaan kesenian yang diwariskan secara turuntemurun dari tiap generasi. Karena itu pandangan hidup suatu masyarakat tercermin dalam berbagai unsur kebudayaan seperti filsafat, kepercayaan, kesenian, kesusasatraan, mode pakaian dan adat istiadat populer (Danandjaja, 1998 : 8). Dari uraian di atas maka Folklor dapat didefinisikan sebagai suatu kebudayaan kolektif, yang tersebar dan diwariskan 
secara turun-temurun, diantara kolektif macam apa saja secara tradisional dalam versi yang berbeda-beda, baik dalam bentuk yang lisan maupun disertai contoh dengan gerak isyarat dan alat bantu mengingat. (Danandjaja, 1997 : 2).

\section{Ciri, Jenis dan Fungsi Folklor}

\subsection{Ciri Folklor}

Folklor sebagai salah satu karya sastra yang menjadi suatu identitas budaya daerah mempunyai ciri-ciri atau tandatanda pengenal yang bersifat iniversal. Tanda-tanda atau ciri-ciri universal tersebut seperti yang dijabarkan oleh Danandjaja (1997 : 3-5) bahwa ciri-ciri Folklor adalah sebagai berikut:

1. Penyebaran dan pewarisan Folklor biasanya dilakukan secara lisan, melalui tutur kata dari mulut ke mulut (atau dengan contoh yang disertai dengan gerak isyarat, dan alat bantu pengingat) dari satu generasi ke generasi selanjutnya.

2. Folklor bersifat tradisional yakni disebarkan dalam bentuk yang relatf tetap atau dalam bentuk yang standart. Folklor disebarkan dalam kolektif tertentu dan waktu yang dipakai cukup lama minimal dua generasi.

3. Folklor ada dalam versi-versi, bahkan varian-varian yang berbeda. Hal ini diakibatkan oleh penyebarannya yang bersifat lisan, sehingga karena beberapa faktor maka dapat berubah.

4. Folklor bersifat anonim, artinya penciptanya tidak diketahui namanya.

5. Folklor mempunyai bentuk berumusatau berpola. Biasanya selalu dimulai dengan kata-kata pembukaan dan penutup yang sudah baku, seperti "Pada jaman dahulu,..., Menurut empunya cerita,..., dan merekapun hidup bahagia selamanya".

6. Folklor mempunyai kegunaan (function) dalam kehidupan bersama suatu kolektif. Kegunaan itu misalnya sebagai alat pendidik, dongeng pelipur lara, protes sosial dan proyeksi keinginan yang terpendam.

7. Folklor bersifat pralogis, artinya mempunyai logika tersendiri tidak sesuai dengan logika pada umumnya. Ciri pengenal ini berlaku terutama bagi Folklor lisan dan sebagian tulisan.

8. Folklor menjadi milik bersama (collective) dari masyarakat tertentu. Hal ini sudah tentu diakibatkan karena penciptanya yang pertama sudah tidak diketahui lagi sehingga setiap angggota masyarakat yang bersangkutan merasa memilikinya.

9. Folklor pada umumnya bersifat polos, lugu sehingga seringkali terlihat kasar, terlalu spontan. Hal ini dapat dimengerti apabila mengingat bahwa Folklor dapat dijadikan sebagai proyeksi emosi yang paling jujur manifestasinya. Tutoli (1994: 4) mengatakan bahwa ciri-ciri budaya menyatu dalam tiga bidang (dalam budaya lisan antara sastra lisan, tradisi lisan dan Folklor mempunyai garapan yang sama sehingga dapat disamakan antara ketiganya. Ciri-ciri tersebut adalah: (a) milik bersama seluruh masyarakat pemiliknya, (b) diturunkan dari generasi ke generasi melalui penuturan lisan, (c) berfungsi dalam kehidupan dan budaya masyarakat (d) dapat diwujudkan dalam berbagai bentuk tingkah laku dari hasil kerja, (e) diwujudkan dalam berbagai variasi sepanjang masa, (f) bersifat anonim dan (g) mengadakan bentuk berpola dalam pelahirannya (penampilannya).

\subsection{Jenis Folklor}

Danandjaja (1997 : 21) menggolongkan jenis Folklor dalam tiga kelompok berdasarkan tipenya yaitu:

1. Folklor lisan (verbal Folklore) adalah Folklor yang berbentuk murni lisan, benar-benar dihasilkan secara lisan dan dituturkan dari mulut ke mulut, yang termasuk dalam kategori ini antara lain 
HUMANIKA Vol. 21 No. 1 (2015) ISSN 1412-9418

Prasasti Plumpungan Sebagai Ikon Batik Kota Salatiga Serta Dampaknya

Bagi Peningkatan Ekonomi Dan Pariwisata

Ken Widyatwati, SS, M.Hum

(a) bahasa rakyat (folk speech) seperti logat, julukan, pangkat tradisional, dan titel kebangsawanan, (b) ungkapan tradisional seperti peribahasa, pepatah, pemeo, (c) pertanyaan tradisional, misalnya teka-teki, (d) puisi rakyat seperti pantun, gurindam dan syair, (e) cerita prosa rakyat, seperti mite, legenda, dongeng dan (f) nyanyian rakyat (folk song).

2. Folklor sebagian lisan (party verball Folklore) adalah Folklor yang bentuknya merupakan campuran unsur lisan dan bukan lisan. Bentuk-bentuk Folklor yang termasuk dalam kelompok ini antara lain: (a) kecakapan tradisional, (b) permainan rakyat, (c) adat istiadat, (d) upacara (e) teater rakyat, (f) tari rakyat dan (g) pesta rakyat.

3. Folklor bukan lisan (non verbal foklore) adalah folklor yang bentuknya memang bukan lisan. Genre ini dibedakan menjadi dua sub kelompok, yaitu kelompok folklor bukan lisan material dan immaterial. Bentuk folklor bukan lisan yang material antara lain (a) arsitektur rakyat misalnya rumah adat, (b) kerajinan tangan rakyat misalnya pakaian adat dan asesori tubuh khas daerah (c) makanan dan minuman tradisional, dan (d) obatobatan tradisional sedangkan yang immaterial adalah (a) gerak isyarat tradisional (gesture), (b) bunyi-bunyian isyarat seperti kentongan untuk komunikasi dan (c) musik rakyat.

\subsection{Fungsi Folklor}

Folklor sebagai suatu kebudayaan tradisional dan milik suatu masyarakat tertentu berfungsi sebagai: (a) sistem proyeksi yaitu sebagai alat pencerminan angan-angan kolektif, (b) alat pengesahan pranata-pranata dan lembaga-lembaga kebudayaan, (c) alat pendidikan anak dan (d) alat pemaksa dan pengawas agar norma-norma masyarakat akan selalu dipatuhi oleh anggota kolektifnya (Danandjaja, 1997 : 19).

Selain fungsi pokok di atas masih terdapat fungsi-fungsi lain yang penting untuk dipahami yaitu: (a) sebagai penebal emosi keagamaan, (b ) sistem khayalan suatu kolektif yang berasal dari halusinasi seseorang yang sedang mengalami gangguan jiwa dalam bentuk makhlukmakhluk gaib, (c) untuk pendidikan anak atau remaja yang bersumber dari kepercayaan masyarakat, (d) sebagian penjelasan yang dapat diterima akan suatu folk terhadap gejala alam yang sangat sukar dimengerti sehingga sangat menakutkan agar dapat diupayakan penanggulangannya dan (e) untuk menghibur orang yang mengalami musibah (Danandjaja, 1997 : 170).

\subsection{Legenda}

Legenda adalah cerita prosa rakyat yang dianggap oleh yang empunya cerita sebagai suatu kejadian yang sungguhsungguh pernah terjadi karena terdapat peninggalan tentang legenda tersebut ( Danandjaja, 1978:66). Legenda seringkali dipandang sebagai sejarah, karena berisi tentang sejarah asal-usul suatu wilayah atau tempat. Legenda biasanya bersifat migratoris yaitu dapat berpindah-pindah sehingga dikenal luas didaerah-daerah lain.

Brunvand (1978: 45) menggolongkan legenda menjadi 4 kelompok yaitu: (a) legenda keagamaan (Religious Legends), (b) Legenda alam gaib ( Supernatural Legends), (c) legenda perseorangan (Personal Legends), dan (d) legenda setempat (Local legends).

a. Legenda keagamaan adalah legenda tentang orang-orang suci dan merupakan kesusastraan agamaq yang disebut sebagai hagiography atau legend of the saints, yang berarti tulisan, karangan atau buku mengenai kehidupan orang-orang saleh atau suc (Danandjaja, 1978:67). Walaupun hagiography telah ditulis tetapi masih 
dianggap sebagai bagian dari foklore lisan karena versi a3walnya masih hidup di masyarakat sebagai tradisi lisan.

b. Legenda alam gaib biasanya berbentuk kisah yang dianggap benar-benar terjadi dan pernah dialami seszeorang. Fungsi legenda semacam ini adealah untuk meneguhkan takhayul dan kepercayaan masyarakat. Berhubung legenda alam gaib sebagian besar merupakan pengalaman pribadi seseorang maka disebut juga de ngan istilah memorat . Memorat adalah legenda alam gaib yang merupakan pengalaman seseorang yang erat hubungannya dengan kepercayaan (Brunvand,1968:89).

c. Legenda perseorangan adalah cerita mengenai tokoh-tokoh tertentu yang dianggap oleh yang empunya cerita benar-benar pernah terjadi. Legenda perseorangan ini memiliki kesamaan cerita di berbagai daerah misalnya dongeng panji ( Danandjaja, 1978:73).

d. Legenda setempat adalah kisah atau cerita yang berhubungan dengan asaqlusul terjadinya suatu tempat, nama tempat, dan bentuk topografi yaitu bentuk permukaan suatu daerah, bukit, jurang daqn sebagainya (Danandjaja 1978:75).

Legenda Prasati Plumpungan termasuk dalam legenda setempat atau local legends karena berisi cerita tentang asal-usul terjadinya Kota Salatiga.

\subsection{Mitos dan Fungsi Mitos}

Menurut Levi Strauss (1974 :254), mitos adalah sesuatu yang sama dengan cerita, dapat berupa cerita rakyat, legenda maupun dongeng. Definisi ini dikuatkan oleh Petit (1975 : 80) yang mengatakan bahwa mitos adalah cerita atau dongeng yang dikisahkan dengan bahasa, atau sebuah cerita sastra. Mitos dapat pula berupa anekdot, dongeng maupun cerita rakyat. Bahkan mitos dapat pula dianggap sakral atau suci dimana ditandai dengan adanya ritual yang menyertai penceritaan mitos atau ritual yang dilegitimasi oleh mitos tersebut. Sedangkan Van Peursen (1978) mengatakan bahwa mitos adalah sebuah cerita yang memberikan pedoman dan arah tertentu bagi kelompok pendukungnya. Cerita ini tidak hanya dituturkan tetapi juga dapat diungkapkan lewat tarian ataupun pementasan wayang. Mitos tidak hanya terbatas pada semacam reportasi mengenai peristiwa yang dulu terjadi, berupa kisah dewa-dewa dan dunia ajaib, tetapi memberikan kepada kelakuan manusia, merupakan pedoman bagi kebijaksanaan manusia.

Menurut Levi Strauss (1974 :229) mitos dianggap sebagai perjanjian dalam masyarakat, karena mitos dapat memberikan informasi tentang pemikiran masyarakat dan kondisinya pada waktu itu, yang dapat mewakili potret masyarakat pada saat itu. Selain itu menurut Levi Strauss (1963 :229) bahwa:

The purpose of myth is to provide a logical model capable of overcoming, a contradiction an impossible a chievemen as it happen, the contradiction is real.

Sehingga fungsi mitos menurut Levi Strauss (163: 229) adalah memberikan pemecahan yang logis untuk mengatasi suatu hal yang tidak mungkin terjadi menjadi suatu hal yang nyata. Hal ini berarti bahwa mitos bukan hanya sekedar cerita tetapi seringkali juga merupakan suatu ungkapan simbolis dari konflikkonflik batiniah yang ada dalam suatu masyarakat, serta menjadi suatu saran untuk mengelakkan, memindahkan dan mengatasi kontradiksi-kontradiksi yang tak terpecahkan, sehingga kontradiksi tersebut dapat dijelaskan dan dapat menjadi masuk akal.

Masyarakat Kota Salatiga sebagian besar sampai saat ini masih mempercayai bahwa legenda asal-usul Kota Salatiga erat 
HUMANIKA Vol. 21 No. 1 (2015) ISSN 1412-9418

Prasasti Plumpungan Sebagai Ikon Batik Kota Salatiga Serta Dampaknya

Bagi Peningkatan Ekonomi Dan Pariwisata

Ken Widyatwati, SS, M.Hum

hubungannya dengan prasasti Plumpunganyang ada di Kota Salatiga. Kepercayaan p-ada mitos dan legenda ini masih mengakar kuat pada masyarakat pendukung kebudayaan tersebut dan tidak bisa dihapuskan begitu saja. Masyarakat percaya bahwa dalam kehidupan di dunia ada kehidupan yang tampak dan ada kehidupan yang tidak tampak. Kehidupan yang tampak dan tidak tampak ini dikuasai oleh roh baik dan roh jahat, dan masingmasing sangat mempengarui kehidupan manusia. Kekuatan yang baik akan mendatangkan kebaikan dan keselamatan, dan kekuatan jahat akan mendatangkan malapetaka dan bencana bagi masyarakat.

Untuk meraih keselamatan dan kebahagiaan tersebut masyarakat sangat mempercayai mitos dan legenda yang dipercaya oleh masyarakat setempat dan masyarakat sangat menghormati kepercayaan tersebut. Wujud kepercayaan dan menghormati legenda asal-usul kota salatiga yang ditandai dengan keberadaan prasasti Plumpungan maka ,masayarakat Salatiga berserta pejabat pemerintah Kota Salatiga sepakat untuyk menjadikan legenda nprasasti Plumpungan sebagai ikon batik khas Kota Salatiga.

\section{Pengertian Resepsi Sastra}

Resepsi sastra yang berkembang di Indonesia saat ini berasal dari teori resepsi yang dikembangkan oleh Jauss dan Iser. Resepsi sastra adalah teori yang bertitik tolak pada pembaca yang memberikan reaksi atau tanggapan terhadap suatu teks. Karena teks sastra bukan satu-satunya objek penelitian, penelitian ini tidak murni meneliti karya sastra. Teks sastra diteliti dalam kaitannya dengan pengaruh, yakni keberterimaan pembaca (Endraswara, 2003: 118). Dalam hal ini maka tanggapan masyarakat Kota Salatiga Jawa Tengah menjadi penting karena merupakan masyarakat yang menerima teks lisan Legenda Prasasti Plumpungan..
Kata resepsi berasal dari bahasa latin yaitu recipare yang berarti menerima. Resepsi pada mulanya merupakan suatu aliran dalam pengkajian sastra yang sejak 1960-an menggeserkan fokus penelitian sastra dari otonomi teks (ergosentris) kepada dunia pembaca. Dalam arti luas, istilah resepsi diperuntukkan bagi setiap aliran dalam penelitian sastra yang mempelajari bagaimana karya sastra diterima oleh pembaca (Noor, 2004: 102103). Resepsi sastra mengakui adanya polisemi pada suatu karya sastra atau teks. Hal ini merupakan hakekat karya sastra atau teks. Suatu teks atau karya sastra akan bermakna apabila karya sastra atau teks tersebut sudah berhubungan dengan pembaca. Teks memerlukan adanya kesan yang tidak mungkin ada tanpa adanya pembaca (Junus, 1985:104).

Pembaca selaku pemberi makna adalah variabel menurut ruang, waktu dan golongan sosial budaya. Hal ini berarti bahwa karya sastra tidak sama pembacaan, pemahaman dan penilaiannya sepanjang masa atau dalam seluruh golongan masyarakat tertentu. Menurut Jauss apresiasi pembaca pertama terhadap sebuah karya sastra akan dilanjutkan dan diperkaya melalui tanggapan-tanggapan yang lebih lanjut dari generasi ke generasi (Jauss, 1982: 12). Teori resepsi sastra juga dapat diterapkan pada folklor sebagian lisan dalam hal ini adalah upacara adat karena folklor sebagian lisan juga termasuk karya sastra. Penyampaiannya menggunakan tradisi adat istiadat yang diturunkan dari generasi satu ke genersi selanjutnya secara turun temurun.

Resepsi sastra adalah teori yang bertitik-tolak pada pembaca yang memberi reaksi atau tanggapan terhadap teks (Jabrohim, 1994: 150). Resepsi sastra merupakan pendekatan penelitian sastra yang tidak berpusat pada teks. Teks sastra tidak hanya satu-satunya objek penelitian, ini tidak murni meneliti sastra. Teks sastra diteliti karena ada kaitannya dengan 
HUMANIKA Vol. 21 No. 1 (2015) ISSN 1412-9418

Prasasti Plumpungan Sebagai Ikon Batik Kota Salatiga Serta Dampaknya

Bagi Peningkatan Ekonomi Dan Pariwisata

Ken Widyatwati, SS, M.Hum

penerimaan penerimaan public (pembaca) (Endraswara, 2003: 118).

Dalam hal ini tanggapan masyarakat Kota Salatiga menjadi penting karena merupakan masyarakat Kota Salatiga berkedudukan sebagai pewaris legenda tersebut.

Penelitian resepsi sastra hadir karena teks sastra bersifat tidak stabil melainkan dinamis sesuai pembacanya. Upaya untuk mendapatkan tanggapan masyarakat atau resepsi penikmat dibutuhkan analisis yang sesuai. Dalam konteks ini teori yang sesuai adalah resepsi sastra Hans Robert Jauss. Menurut Jauss, apresiasi pembaca pertama terhadap sebuah karya sastra akan dilanjutkan dan diperkaya melalui tanggapan-tanggapan yang lebih lanjut dari generasi ke generasi (Jauss, 1982: 12-13). Oleh Jauss resepsi sastra disebut sebagai estetika resepsi yaitu (ilmu keindahan) yang didasarkan pada tanggapantanggapan atau resepsi pembaca terhadap karya sastra. Karya sastra tidak mempunyai arti tanpa pembaca/ penikmat sastra yang menanggapinya. Karya sastra mempunyai nilai karena ada pembaca yang menilai (Pradopo, 1995: 206).

Pada penelitian ini objek analisis adalah deskripsi cerita legenda prasasti Plumpungan laut yang termasuk dalam kategori folklor lisan. Untuk dapat memahami resepsi terhadap suatu karya harus memperhatikan sistematika unsurunsur pembentuk resepsi sastra (Junus, 1985: 52). Pembaca dibedakan menjadi dua jenis yaitu pembaca biasa dan pembaca ideal. Pembaca biasa adalah pembaca dalam arti yang sebenarnya yang membaca suatu karya sastra bukan untuk bahan penelitian. Pembaca biasa dalam penelitian ini adalah masyarakat Kota salatiga, sedangkan pembaca ideal adalah pembaca yang dibentuk oleh peneliti dari pembaca biasa. Pembaca ideal dibedakan menjadi dua jenis yaitu pembaca implisit dan pembaca eksplisit. Pembaca implisit memainkan peran bagaimana suatu teks dapat dibaca. Pembaca implisit adalah tokoh masyarakat yang menguasai cerita, sedangkan pembaca eksplisit adalah pembaca berpengetahuan yang kompeten dalam pemakai bahasa juga berkompeten dalam sastra (Junus, 1985: 52-54) dalam hal ini adalah peneliti.

\section{Pendapatan Daerah}

\section{Dwipayana}

(2003:12) dalam bukunya Membangun Good Governence di Desa menjelaskan bahwa otonomi daerah hendaknya bersandar pada visi jangka panjang serta memberikan makna dan manfaat bagi negara,bangsa dan masyarakat Indonesia.

Pertama otonomi daerah sebagai sebuah sistem dan keyakinan membangun integrasi nasional, berarti mengandung makna kesatuan negara (State unity), tetapi juga daerah berkapasitas kuat dan demokratis (partisipasif, akuntabel,dan responsif) serta masyarakat yang kohesif ,pluralis,partisipatif dan mandiri.

$$
\text { Kedua }
$$

otonomi daerah berarti berusaha memberikan pengakuan terhadap eksistensi lokal yang beragam,sumberdaya ekonomi sebagai basis kehidupan masyarakat lokal.

Berdasarkan UU no 32 tahun 2004 tentang otonomi daerah pemerintah pusat berusaha untuk mendorong daerah membangun pemerintahan lokal yang lebih akuntabel dan responsif serta dapat membangkitkan prakarsa dan potensi lokal. Peningkatan potensi lokal bertujuan untuk meningkatkan pendapatan daerah. Di Salatiga terdapat banyak potensi lokal yang dapat membantu peningkatan ekonomi dan pariwisata, salah satunya adalah Prasasti Plumpungan. Prasasti Plumpungan adalah prasasti yang dijadikan sebagai peninggalan cagar budaya Kota Salatiga yang juga dijadikan sebagai ikon batik kota Salatiga. 
HUMANIKA Vol. 21 No. 1 (2015) ISSN 1412-9418

\section{METODE PENELITIAN IV.Data}

Data adalah informasi atau keterangan mengenai segala sesuatu yang berkaitan dengan tujuan penelitian. Datadata dalam penelitian ini diperoleh dari hasil wawancara, observasi, dokumentasi foto pada saat penelitian. Data-data ini diperoleh dari : (a) Buku- buku, majalah, koran yang memuat informasi tentang legenda prasasti plumpungan (b) hasil wawancara dengan responden (sesepuh ,juru kunci prasasti plumpungan dan tokoh masyarakat kota salatiga) mengenai asalusul terjadinya Kota Salatiga , keberadaan prasasti Plumpungan dan sejarah batik Plumpungan serta . makna mitos, serta legenda prasasti plumpungan, (c) foto dan dokumentasi tentang prasasti plumpungan dan batik plumpungan.

Dengan syarat tersebut diharapkan data-data yang diperoleh dapat lebih akurat dan tepat. Pengumpulan data dalam penelitian ini menggunakan sumber data primer dan sumber data sekunder.

Sumber data primer adalah sumber data yang diperoleh secara langsung pada saat penelitian. Data ini diperoleh dari hasil wawancara terhadap sesepuh, juru kunci prasasti plumpungan dan tokoh masyarakat kota Salatiga.

Sumber data sekunder adalah sumber data yang diperoleh dari buku-buku, makalah, majalah dan koran yang berkaitan dengan prasasti Plumpungan dan batik Plumpungan serta . makna mitos dan legenda prasasti plumpungan. Data sekunder ini digunakan untuk perbandingan dan memperkaya data penelitian.

\section{Teknik Pengumpulan Data}

Dalam rangka pengumpulan data yang diperlukan dalam penelitian maka terlebih dahulu perlu dilakukan identifikasi cara pengumpulannya. Pengumpulan data dalam penelitian ini dengan menggunakan metode wawancara. Wawancara dilakukan dengan tujuan untuk mendapatkan data secara langsung dari informan.

Teknik wawancara yang digunakan adalah wawancara tidak terstruktur artinya wawancara yang bersifat bebas, santai dan memberikan kebebasan seluas- luasnya pada informan untuk mengeluarkan pandangan, perasaan, pikiran, keyakinan,dan kepercayaannya tanpa diatur peneliti. Selain wawancara peneliti juga mengumpulkan data dari buku-buku, majalah,koran artikel atau jurnal yang berkaitan dan memberikan informasi tentang prasasti Plumpungan dan batik Plumpungan serta, makna mitos dan legenda prasasti plumpungan

\section{Uji Validitas Data}

Agar diperoleh temuan dan interpretasi yang valid sebagai sumber data penelitian, maka perlu diteliti kredibilitasnya dengan menggunakan teknik-teknik perpanjangan kehadiran peneliti di lapangan, observasi yang mendalam, triangulasi (mempergunakan beberapa sumber, metode, peneliti, teori), pembahasan denan teman sejawat dan pelacakan kesesuaian hasil. Teknik yang digunakan untuk uji validitas data dalam penelitian ini adalah:

1. Perpanjangan keikutsertaan yaitu menambah waktu untuk observasi dan wawancara sehingga dapat diperoleh data tambahan dari para informan.

2. Triangulasi, peneliti berusaha mengumpulkan data yang sama dari beberapa sumber data (koran, majalah, artikel, jumal) menggunakan metode yang bebeda untuk mengumpulkan data yang sama, menerapkan beberapa teori untuk mebahas data yang sama sehingga hasil pembahasan dapat relevan dengan tujuan penelitian.

3. Diskusi dengan teman sejawat yang memiliki latar belakang yang sama, sehingga dapat menambah wawasan peneliti dalam pengolahan dan pembahasan data. 


\section{Teknik Analisis Data}

Teknik analisis data yang digunakan dalam penelitian ini adalah teknik analisis data langsung, artinya analisis data dilakukan sejak awal pengumpulan data dan terus berlanjut sampai akhir penelitian.

\section{ANALISIS}

\section{Asal-usul Kota Salatiga}

Asal - usul kota Salatiga berasal dapat dilihat dari beberapa sumber. Sumber tersebut antara lain Babad Demak, Stads Gementee Solotigo, Prasasti Plumpungan dan cerita rakyat (Pemerintah Daerah Kotamadya Salatiga, 1995:20). Babad Demak disajikan dalam bentuk tembang Asmaradana dan Kinanti yang kemudian dialihbahasakan oleh sejarawan untuk dijadikan bahan pembelajaran. Stands Gemeentee Solotigo merupakan surat keputusan gubernur Hindia Belanda pada tanggal 25 Juli 1917 No. 1 (Staatsbland 1917 266). Surat keputusan ini sematamata hanya untuk kepentingan pemerintah Hindia Belanda, sehingga perlu dilakukan pembahasan lebih lanjut. prasasti Plumpungan merupakan satu-satunya sumber tertulis paling tua dan utama yang dapat memberikan gambaran tentang cikal bakal hari lahirnya kota Salatiga. Prasasti tersebut sebagai bukti bahwa kota Salatiga merupakan daerah Hampra. Daerah Hampra yaitu daerah bebas pajak oleh raja pada masa itu. Berdasarkan hal tersebut di atas pemerintah kota Salatiga menetapkan hari jadi kota Salatiga dengan mengacu pada prasasti Plumpungan tertanggal 24 Juli tahun 750, sehingga sampai saat ini peringatan hari jadi Kota nSalatiga dilaksanakan setiap tanggal 24 Juli. Sumber yang terakhir adalah cerita rakyat. Pada kesempatan ini peneliti akan mengkaji asal usul kota Salatiga berdasarkan cerita rakyat. Cerita rakyat "Asal-usul Kota Salatiga" merupakan salah satu cerita rakyat yang tumbuh di kota Salatiga. Cerita ini dimasukkan dalam sastra lisan karena penyebarannya secara turun temurun, yakni dari mulut ke mulut dari satu generasi ke generasi berikutnya. Penyebaran cerita secara lisan menjadi salah satu sebab munculnya banyak versi cerita asal-usul terjadinya Kota Salatiga. Berdasarkan pembagian dalam Foklore maka cerita rakyat asal-usul Kota Salatiga dikatagorikan sebagai legenda . Legenda adalah bentuk foklore lisan yang bercerita tentang terjadinya suatu daerah, atau wilayah yang di percaya keberadaannya oleh masyarakat setempat.

Ada beberapa sumber yang dijadikan dasar untuk mengungkap asal usul Salatiga, yaitu yang berasal dari cerita rakyat, prasasti maupun penelitian dan kajian yang cukup detail. Dari beberapa sumber tersebut Prasasti Plumpungan-lah yang dijadikan dasar asal usul Kota Salatiga. Berdasarkan prasasti ini Hari Jadi Kota Salatiga dibakukan, yakni tanggal 24 Juli 750 yang ditetapkan dengan Peraturan Daerah Tingkat II Kota Salatiga Nomor 15 Tahun 1995 tentang Hari Jadi Kota Salatiga.

Prasasti Plumpungan sebagai dasar atau cikal bakal lahirnya Kota Salatiga, prasasti ini di tulis pada sebuah batu besar berjenis batu andesit yang mempunyai ukuran sebagai berikut panjang $170 \mathrm{~cm}$, lebar $160 \mathrm{~cm}$ dengan garis lingkar 5 meter .

Prasasti ini di beri nama Plumpungan karena prasasti ini berada di wilayah dukuh Plumpungan.

Berdasar prasasti di Dukuh Plumpungan, Desa Kauman Kidul, Kecamatan Sidorejo, maka Kota Salatiga sudah ada sejak tahun 750 Masehi, pada waktu itu Salatiga merupakan daewrah perdikan. Daerah Perdikan adalah suatu daerah yang berada dalam wilayah sebuah kerajaan, dan daerah ini dibebaskan dari segala kewajiban membayar pajak atau upeti karena daerah tersebut dipandang memiliki kekhususan tertentu berdasarkan keputusan raja dari kerajaan tersebut. 
HUMANIKA Vol. 21 No. 1 (2015) ISSN 1412-9418

Pemberian tanah perdikan merupakan peristiwa yang sangat istimewa dan langka, karena hanya diberikan kepada desa-desa yang benar-benar berjasa kepada raja. Untuk mengabadikan peristiwa itu maka raja menulis dalam Prasasti Plumpungan Srir Astu Swasti Prajabhyah, yang artinya: "Semoga Bahagia, Selamatlah Rakyat Sekalian". Prasasti Plumpunga ditulis pada hari Jumat, tanggal 24 Juli tahun 750 Masehi.

Pada zaman penjajahan Belanda ditetapka batas dan status Kota Salatiga, berdasarkan Staatsblad 1917 No. 266 Mulai 1 Juli 1917 didirikan Stadsgemeente Salatiga yang daerahnya terdiri dari 8 desa. Karena letak geografis Kota Salatiga yang dikelilingi banyak Gunung seperti Gunung Ungaran, Telomoyo, Merbabu, Merapi maka Kota Salatiga mempunyai udara sejuk dan pemaqndangan alam yang sangat indah . Kota Salatiga terkenal karena keindahannya sehingga pada masa penjajahan Belanda, Kota Salatiga mendapat julukan sebagai Kota Salatiga yang Terindah di Jawa Tengah.

\section{Prasasti Plumpungan}

Sejarah Kota Salatiga berkaitan erat dengan Prasasti Plumpungan. Prasasti Plumpungan berada di Dukuh Plumpungan yang berjarak sekitar $2 \mathrm{~km}$ dari tugu bundaran Kota Salatiga kearah Beringin kurang lebih $20 \mathrm{~km}$. Prasasti Plumpungan menjadi bukti sejarah yang berisi ketetapan hukum mengenai status tanah perdikan (swatantra) bagi desa Hampra Salatiga. Berdasarkan pada prasasti Plumpungan maka ditetapkan hari lahir kota Salatiga 24 Juli tahun 750 sehingga peringatan hari jadi kota Salatiga diperingati setiap tanggal 24 Juli..

Prasasti Plumpungan ditulis dalam bahasa Jawa kuna dan bahasa Sanskerta di atas batu Andesit dengan ukuran panjang $170 \mathrm{~cm}$, lebar $160 \mathrm{~cm}$, diameter $5 \mathrm{~m}$ dengan berat kuang lebih mencapai 20 ton. Saat ini kondisi prasasti plumpungan terawat dengan baik, jalan menuju lokasi Prasasti Plumpungan baik dan mudah dijangkau. Dalam buku yang berjudul Salatiga - Sketsa kota lama karya Eddy Supangkat yang terbit pada tahun 2007 dan diterbitan oleh Griya Media. Buku tersebut menguraikan dengan jelas tentang asal-usul Kota salatiga, sejarah Kota Salatiga dengan jelas. Prasasti plumpungan ditulis pada 24 Juli tahun 750 atau sekitar abad 8 .

Pembangunan obyek wisata Taman Cagar Budaya Prasasti Plumpungan merupakan pembangunan kawasan budaya yang didalamnya terdapat Prasasti Plumpungan, di situ terdapat sebuah batu yang bertuliskan dengan huruf Jawa Kuno berbahasa Sansekerta yang bertuliskan dengan bagian awal berbunyi Shir Astu Swasti Prajabyah yang berarti semoga selamat dan sejahtera bagi semua rakyat . Kalimat ini menandai bahwa Prasasti Plumpungan dibuat pada masa perintahan kerajaan Mataram Hindu di Pulau Jawa.

Prasasti Plumpungan yang ditulis pada tanggal 24 Juli 750 M merupakan salah satu bukti konkrit tentang lahirnya Salatiga . Prasasti Plumpungan dapat dikembangkan sebagai salah satu tujuan wisata di Kota Salatiga dan untuk membantu pelestarian cagar budaya yang mengandung nilai budaya tradisional tinggi. Sebagai salah satu objek wisata Prasasti Plumpungan mempunyai nilai ekonomi yang tinggi.

\section{Batik Plumpungan sebagai Ikon Batik Kota Salatiga \\ a. Sejarah Motif Batik Plumpungan}

Motif Batik Plumpungan
pertamakali diciptakan pada tahun 2004 oleh Bambang Pamulardi, Msi., seorang PNS Pemerintah Kota Salatiga warga Dukuh Klasemen, Kelurahan Mangunsari, Salatiga.

$$
\text { Motif batik Plumpungan }
$$

Inspirasinya berasal dari prasasti Plumpungan, yakni prasasti yang 
menandakan lahirnya Kota Salatiga sesuai tanggal yang tertera pada Prasasti Plumpungan yaitu 24 Juli 750 Masehi. Prasasti ini juga merupakan salah satu prasasti tertua di Indonesia.

Ciri khas batik Plumpungan adalah motifnya yang selalu memiliki bentuk dasar seperti bentuk prasasti Plumpungan yang terdiri dari satu batu besar dan satu batu kecil. "Bentuk dasarnya selalu menyerupai bentuk batu prasasti Plumpungan, namun pada perkembangannya juga bisa dibentuk menyerupai kupu-kupu, ikan, kura-kura, dan lain-lain," jelas Bambang Pamulardi, penemu motif batik Plumpungan yang juga mendirikan Pusat Kerajinan Tangan Batik Plumpungan Prasasti.

Di pusat kerajinan batik Plumpungan, semua batik Plumpungan merupakan batik buatan tangan. Warnawarna cerah seperti kuning, biru, merah muda, dan hijau mendominasi kain-kain batik ini. Bahannya juga beragam dari katun hingga sutra.

Mengikuti selera pasar yang cenderung lebih memilih motif batik tradisional, Bambang kemudian mengkombinasikan motif batik Plumpungan dengan motif-motif batik tradisional yang sudah ada, seperti kawung. Sambutannya cukup baik. Menurut Bambang kendala justru dihadapi dalam hal pemasaran. Dulunya, sangat sedikit sekali masyarakat yang paham akan sejarah budaya yang ada di lingkungannya, tepatnya tentang keberadaan Prasasti Plumpungan. Namun semenjak batik ini hadir, masyarakat menjadi tahu dan mengenal peninggalan sejarah yang patut dirawat keeksistensiannya.

Batik tidak selamanya bermotif tradisional dan berwarna tua. Batik Plumpungan dari Kota Salatiga, misalnya. Batik yang satu ini bergaya kontemporer, memiliki motif unik dan berwarna cerah.
Batik Plumpungan merupakan karya seni batik kontemporer. Motif dasarnya didesain dari gambar Prasasti Plumpungan yaitu Prasasti yang menanadai lahirnya Kota Salatiga, Prasasti Plumpungan merupakan peninggalan Raja Bhanu tahun 750 Masehi.

Motif Batik Plumpungan dasarnya adalah dari bentuk Prasasti Plumpungan yang terdiri dari dua buah batu besar dan batu kecil. Pencarian motif batik ciri khas kota salatiga dimulai pada tahun 2000 dengan oleh beberapa warga Salatiga yang menginginkan Salatiga mempunyai batik khas Salatiga untuk memeringati hari jadi kota salatiga. Di tahun tersebut pemerintah kota Salatiga menginginkan Kota Salatiga mempunyai batik khas Salatiga. Pada awlanya motif diambil dari jenis tanaman yang ada di Salatiga dan sempat dibuat desainnya seperti di bawah ini.

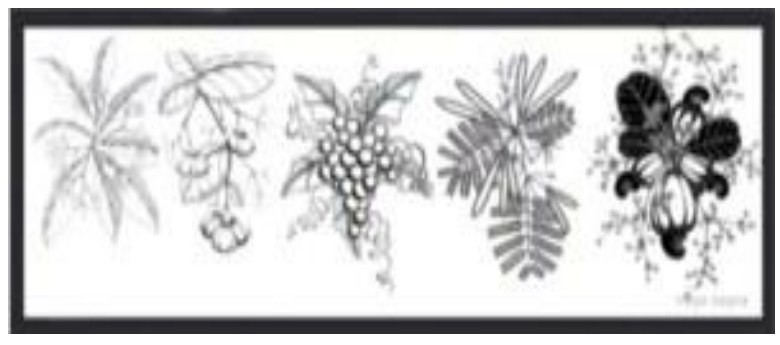

Tetapi setelah melihat foto batu prasasti Plumpungan yang ada di Kantor Pariwisata Kota Salatiga, Jalan Adi Sutjipto,tim terinspirasi untuk membuat desain batik dengan dasar bentuk Prasasti Plumpungan sebagai modelnya dengan pemikiran bahwa motif tanaman sudah banyak yang dipakai sebagai desain motif batik khas dari beberapa daerah di nusantara seperti motif bati Surakarta, Jogjakarta, Lasem,Semarang,Pekalongan dan sebagainya. Sehingga apabila dasar motif adalah bentuk prasasti maka desain motif ini bisa menjadi ciri khas motif batik Salatiga yang berbeda dengan motif batik diberbagai daerah di Indonesia. Selain hal tersebut keberadaan Prasasti Plumpungan juga mendasari munculnya legenda tentang 
HUMANIKA Vol. 21 No. 1 (2015) ISSN 1412-9418

Prasasti Plumpungan Sebagai Ikon Batik Kota Salatiga Serta Dampaknya

Bagi Peningkatan Ekonomi Dan Pariwisata

Ken Widyatwati, SS, M.Hum

prasasti Plumpungan yang kemudian terungkap bahwa Prasasti Plumpungan merupakan bukti sejarah berdirinya Kota Salatiga.

\section{b. Cirikhas Batik Plumpungan}

Batik Plumpungan pada setiap motifnya mempunyai ciri-ciri bergambar dua bulatan berukuran besar dan kecil sedikit lonjong dalam satu kesatuan, bentuk ini apabila dilihat dari sudut pandang atas menyerupai bentuk dari Prasasti Plumpungan.

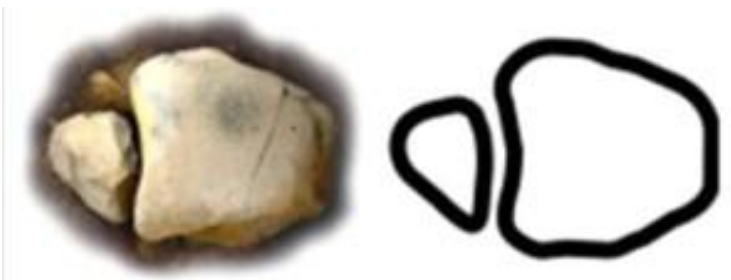

Dua gambar bulatan besar dan kecil lonjong ini akan menjadi pola dasar beraneka ragam motif batik Plumpungan sesuai dengan keinginan, kreatifitas dan imajinasi desainer dan pembatik.

\section{Batik Plumpungan Bagi Peningkatan Pendapatan dan Pariwisata Kota Salatiga}

Dwipayana (2003:12) dalam bukunya Membangun Good Governence di Desa menjelaskan bahwa otonomi daerah hendaknya bersandar pada visi jangka panjang serta memberikan makna dan manfaat bagi negara,bangsa dan masyarakat Indonesia.

Pertama otonomi daerah sebagai sebuah sistem dan keyakinan membangun integrasi nasional, berarti mengandung makna kesatuan negara (State unity), tetapi juga daerah berkapasitas kuat dan demokratis (partisipasif, akuntabel,dan responsif) serta masyarakat yang kohesif ,pluralis,partisipatif dan mandiri.

Kedua otonomi daerah berarti berusaha memberikan pengakuan terhadap eksistensi lokal yang beragam,sumberdaya ekonomi sebagai basis kehidupan masyarakat lokal.

Berdasarkan UU no 32 tahun 2004 tentang otonomi daerah pemerintah pusat berusaha untuk mendorong daerah membangun pemerintahan lokal yang lebih akuntabel dan responsif serta dapat membangkitkan prakarsa dan potensi lokal. Peningkatan potensi lokal bertujuan untuk meningkatkan pendapatan daerah. Di kota Salatiga terdapat banyak potensi lokal yang dapat membantu peningkatan ekonomi dan pariwisata, salah satunya adalah Prasasti Plumpungan. Prasasti Plumpungan adalah prasasti yang dijadikan sebagai peninggalan cagar budaya Kota Salatiga yang juga dijadikan sebagai ikon batik kota Salatiga.

Tujuan akhir program pembangunan adalah untuk meningkatkan taraf hidup anggota masyarakat melalui peningkatan pendapatan. Tingkat pendapatan tersebut sering digunakan sebagai indikator tingkat keberhasilan pembangunan ekonomi suatu komunitas atau daerah. Namun, bila dilihat lebih jauh peningkatan pendapatan daerah belum menjamin perbaikan dan peningkatan kesejahteraan anggota masyarakat luas karena tingkat pendapatan yang bervariasi antarrumah tangga sesuai dengan tingkat penguasaan sumberdaya dan kemampuan mengelola keuangan dan pendapatan masing-masing . Dengan perkataan lain bahwa peningkatan pendapatan suatu komunitas tidak selalu diikuti perbaikan distribusi di antara anggota atau kelompok masyarakat. Ketimpangan distribusi pendapatan dan tingkat pendapatan tergantung pada tipe dan tingkat pembangunan ekonomi tiap daerah. Tingkat pendapatan yang meningkat dan distribusi yang membaik terjadi pada keadaan pembangunan ekonomi yang mampu meningkatkan pendapatan sektor tradisional (traditional sector enrichment) dan memperlebar sektor modern (modern sector enlargement) dalam kelompok 
masyarakat. Secara ringkas dapat dikatakan bahwa distribusi pendapatan cenderung membaik pada kasus pertumbuhan ekonomi yang terjadi sebagai akibat peningkatan pendapatan secara signifikan pada sektor tradisonal (traditonal sector enrichment). Sebaliknya distribusi pendapatan semakin memburuk karena peningkatan pendapatan sektor modern (Field, 1979). Sementara More (1990) berpendapat bahwa tingkat ketidakmerataan pendapatan, pada kenyataannya mengikuti pola berbentuk $\mathrm{U}$ terbalik untuk kasus pertumbuhan dengan melebarnya sektor berpendapatan tinggi (highincome sector enlargement growth).

Berdasarkan hal tersebut di atas maka, tingkat ketidakmerataan distribusi pendapatan tidak berkorelasi dengan pendapatan per kapita, tetapi lebih dipengaruhi oleh faktor-faktor lain yang berkaitan dengan bentuk kurva hubungan kedua parameter tersebut. Secara umum faktor-faktor yang berkaitan dan berpengaruh terhadap distribusi pendapatan rumah tangga dikategorikan ke dalam faktor internal dan faktor eksternal. Khusus faktor internal adalah faktor yang berasal dari intern rumah tangga itu sendiri. Faktor-faktor tersebut meliputi sumberdaya tenaga kerja rumah tangga dan komponen pendapatan itu sendiri (Becker, 1993).

Kesejahteraan adalah sebuah tata kehidupan dan penghidupan sosial,material, maupun spiritual yang diikuti dengan rasa keselamatan, kesusilaan dan ketentraman diri, rumah tangga serta masyarakat lahir dan batin yang memungkinkan setiap warga negara dapat melakukan usaha pemenuhan kebutuhan jasmani, rohani dan sosial yang sebaikbaiknya bagi diri sendiri, rumah tangga, serta masyarakat dengan menjunjung tinggi hak-hak asasi (Rambe, 2004).

Pemerintah juga turut mempunyai peranan penting dalam program peningkat kesejahteraan masyarakat daerah. Dari hasil penelitian yang dilakukan Lestari dan
Wirjidirdjo (2010), bahwa terdapat 45 strategi pengembangan usaha skala kecil. Strategi pemerintah tersebut merupakan kebijakan yang bersifat perbaikan manajemen sistem klaster bagi para pengrajin di daerah . Strategi serta program-program yang direncanakan tersebut menjadi tidak ada artinya apabila tidak didukung dengan kebijakan pemerintah di level makro, seperti harga BBM dan kebutuhan pokok masyarakat.

Seperti halnya pengrajin batik Plumpungan kota Salatiga tidak akan berkembang apabila pemerintah kota Salatiga dalam hal ini Pemerintah Kota dan Dinas perindustrian kota Salatiga tidak ikut serta dalam upaya mengembangan pusat industri kecil Batik Plumpungan.

Pusat Industri Batik Plumpungan di salatiga secara administratif masuk wilayah Kelurahan Kutawinangun Salatiga yang sebagian besar masyarakatnya merupakan petani dan sebagian besar para istri adalah ibu rumah tangga. Hal ini menyebabkan sebelum adanya pusat industri kecil batik Plumpungan sebagian besar masyarakat mempunyai pendapatan yang kurang ( Miskin).

Di Kelurahan Kutawinangun Salatiga merupakan salah satu Kelurahan yang sebagian penduduknya bermata pencaharian sebagai petani dan buruh . Umumnya masyarakat di Kelurahan Kutawinangun tinggal di daerah perkampungan dengan rata-rata tingkat ekonomi warganya adalah menengah ke bawah, banyak diantaranya tinggal di gang-gang kecil,padat dan pengap, ukuran rumah tangga yang cukup sempit. Sebagian besardari penduduk telah mempunyai rumah sendiri walaupun rumah itu sederhana dan peninggalan dari orang tua . Sebagian rumah penduduk masih terbuat dari kayu dan beratapkan genting atau seng.Sebagian besar masyarakat yang bermata pencaharian sebagai petani dan buruh berumur 30 th sampai 45 th, dari ke 30 responden mayoritas berumur 30 th sampai 45 th yaitu sebanyak 24 responden atau $72 \%$. 
HUMANIKA Vol. 21 No. 1 (2015) ISSN 1412-9418

Tabel 1.

\section{Rata-rata umur Penduduk dan Sumber Pendapatan}

$\begin{array}{llc}\text { Umur(thn) } & \text { Jumlah(org) } & \text { Persentase (\%) } \\ 20-30 & 5 & 15 \\ 31-45 & 20 & 70 \\ >45 & 5 & 15\end{array}$

Jumlah 30100

Sumber: Data primer diolah, 2014

Dalam keseharian kehidupan rumah tangga masyarakat Kelurahan Kutowinangun Salatiga tidak hanya kepala keluarga saja yang bekerja, tetapi istri juga turut andil dalam meningkatkan pendapatan rumah tangga. Hal ini dilakukan karena pendapatan suami terkadang tidak cukup untuk memenuhi kebutuhan keluarga sehari-hari. Sebagian besar ibu rumah tangga memiliki pekerjaan sampingan dalam menunjang kebutuhan keluarga.Pekerjaan sampingan tersebut seperti merupakan buruh pabrik,pedagang eceran, dan penjual toko klontong. Didasarkan dari jumlah responden diperoleh responden.informasi bahwa jumlah istri yang bekerja sebanyak 21 orang atau kurang lebih $48 \%$ dari total responden.

Dengan adanya kerajinan batik Plumpungan sekarang ini banyak ibu rumahtangga yang bekerja di sentra-sentra batik Plumpungan. Tingkat kesejahteraan keluarga dipengaruhi oleh beberapa faktor yangterdiri dari faktor ekonomi dan non ekonomi. Faktor ekonomi biasanya berkaitan dengan kemampuan keluarga dalam memperoleh pendapatan. Keluarga yang memiliki pendapatan rendah dikatakan keluarga tidak sejahtera (miskin). Secara umum kemiskinan dipandang sebagai ketidakmampuan dari aspek ekonomi dalam pemenuhan kebutuhan dasar makanan dan bukan makanan. Masyarakatyang memiliki ratarata pengeluaran/pendapatan perkapita perbulan dibawah garis disebut masyarakat miskin.

Kemiskinan dapat terjadi akibat tidak dimilikinya sumberdaya yang berkualitas dan memadai, yaitu rendahnya kualitas sumberdaya alam dan rendahnya kualitas sumberdaya manusia yang dimiliki oleh kelompok atau masyarakat Banyaknya permasalahan kemiskinan pada masyarakat ,disebabkan masyarakatnya hidup dalam suasana alam yang selalu diliputi ketidakpastian (uncertainty) dalam menjalankan usahanya. Selain harus berlomba-lomba dalam perebutan sumber alam juga harus menghadapi pergantian musim antara musim kemarau dan musim penghujan yang selalu ada tiap tahunnya dan lamanya pun tidak dapat diketahui. Kondisi alam yang seperti inilah yang juga berperan menghambat peningkatan pendapatan sehingga jumlah warga masyarakat yang berada didalam lingkaran kemiskinan tiap tahun terus meningkat.

Minimnya pekerjaan alternatif bagi masyarakat ditunjukkan oleh masih sempitnya akses perekonomian dari sektor non-pertanian, dalam hal ini mayoritas hanya bisa menggantungkan perekonomiannya dari hasil berdagang eceran, buruh psabrik dan petani. Meskipun demikian, suatu wilayah yang memiliki sumberdaya alam yang terbatas, namun apabila didukung oleh sumberdaya manusia yang menguasai keterampilan dan teknologi, maka sumberdaya alam itu dapat dikelola secara baik untuk meningkatkan pendapatan yang optimal. Jika digunakan teknologi untuk mengelola sumberdaya alam yang terdapat pada wilayah tersebut, secara tidak langsung telah membuka lapangan kerja bagi masyarakat di daerah itu.

Hal ini sejalan dengan penelitian Rejekiningsih (2011) yang memaparkan bahwa masyarakat perlu mengolah alam untuk memenuhi kebutuhan hidupnya, berhasil tidaknya usaha tersebut sangat 
tergantung pada manusia itu sendiri. Kondisi alam hanya membatasi usaha manusia yang berisiniatif untuk melakukan uusaha produktif yang diyakini akan meningkatkan kesejahteraan keluarga dan lingkungannya tanpa menunggu bantuan dari pemerintah.

Mayoritas tingkat pendidikan masyarakat Kutowinangun Salatiga adalah lulusan Sekolah Menengah Atas (SMA), dan masyarakat cenderung suka bekerja sebagai buruh pabrik karena banyak pabrik yang berada disekitar kota salatiga atau tidak jauh dari kota Salatiga seperti di Bawen, Ambarawa, Karangjati dan Ungaran. Hal ini sangat mempengaruhi pola pikir masyarakat Kutowinangun dalam pengambilan keputusan, hal ini terkait juga dengan pengetahuan dan teknologi . Tetapi setelah berdiri sentrasentra batik Plumpungan lebih banyak masyarakat yang bekerja di sentra batik sehingga hasil atau pendapatan masyarakat menjadi lebih meningkat.

$$
\text { Strategi kebijakan pemerintah }
$$
dalam penanggulangan kemiskinan di Kutowingun Salatiga berupa Raskin, BLSM, dan bantuan pemberian modal pinjaman lunak dari bank pemerintah. Adanya bantuan-bantuan tersebut dapat meringankan biaya hidup masyarakat Program-program bantuan dari pemerintah yang aktif diterima oleh masyarakat adalah Raskin dan BLSM yang merupakan salah satu program kompensasi selain dari beras miskin. BLSM diberikan karena terjadi kenaikan harga bahan bakar minyak (BBM khususnyapremium dan solar) bersubsidi. Biasanya penyaluran bantuan Raskin dan BLSM ini melalui aparatur desa. Selain hal tersebut bantuan permodalan dari pemerintah kota Salatiga berupa pinjaman lunak sangat membantu masyarakat untuk membuka sentra batik Plumpungan.

\section{Selain strategi pengentasan} kemiskinan yang dikeluarkan pemerintah guna penanggulangan kemiskinan.
Masyarakat juga mempunyai strategi untuk penanggulangan kemiskinan yaitu dengan mendirikan sentra batik bersama sebagai kelompok usaha bersama .Hal ini disebabkan selain pekerjaan menjadi ringan dan tidak rumit, juga menguntungkan secara ekonomis, permintaan pasar bagus, biaya produksi rendah dan dapat dilakukan sepanjang tahun.

Kelompok Usaha Bersama ini merupakan kelompok para pengrajin Batik yang membuat batik dan mendapatkan pinjaman modal baik individu maupun kelompok. Selain mendapat pinjaman modal pengrajin juga tidak mengalami kesulitan menjual hasil karena dengan adannya sentra Batik para pembeli yang biasanya terdiri dari para wisatawan baik domestik, lokal langsung datang ke sentra batik tersebut.

\section{KESIMPULAN}

Berdasarkan uraian diatas maka dapat ditarik kesimpulan, yang meliputi:

1. Prasasti Plumpungan sebagai dasar atau cikal bakal lahirnya Kota Salatiga, prasasti ini di tulis pada sebuah batu besar berjenis batu andesit yang mempunyai ukuran sebagai berikut panjang $170 \mathrm{~cm}$, lebar $160 \mathrm{~cm}$ dengan garis lingkar 5 meter .Prasasti ini di beri nama Plumpungan karena prasasti ini berada di wilayah dukuh Plumpungan.

2. Motif batik Plumpungan Inspirasinya berasal dari prasasti Plumpungan, yakni prasasti yang menandakan lahirnya Kota Salatiga sesuai tanggal yang tertera pada Prasasti Plumpungan yaitu 24 Juli 750 Masehi. Prasasti ini juga merupakan salah satu prasasti tertua di Indonesia.

3. Ciri khas batik Plumpungan adalah motifnya yang selalu memiliki bentuk dasar seperti bentuk prasasti Plumpungan yang terdiri dari satu batu besar dan satu batu kecil. 
HUMANIKA Vol. 21 No. 1 (2015) ISSN 1412-9418

Prasasti Plumpungan Sebagai Ikon Batik Kota Salatiga Serta Dampaknya

Bagi Peningkatan Ekonomi Dan Pariwisata

Ken Widyatwati, SS, M.Hum

4. Di pusat kerajinan batik Plumpungan , semua batik Plumpungan merupakan batik buatan tangan. Warna-warna cerah seperti kuning, biru, merah muda, dan hijau mendominasi kain-kain batik ini. Bahannya juga beragam dari katun hingga sutra

5. Pusat Industri Batik Plumpungan di salatiga secara administratif masuk wilayah Kelurahan Kutawinangun Salatiga yang sebagian besar masyarakatnya merupakan petani dan sebagian besar para istri adalah ibu rumah tangga. Dengan adanya sentra industri kecil batik Plumpungan sebagian besar masyarakat mengalami peningkatan pendapatan karena dengan adanya sentra industri kecil Batik Plumpungan banyak wisatawan,lokal,domestik maupun manvanegara yang datang untuk membeli batik plumpungan.

\section{DAFTAR PUSTAKA}

Dwipayana,Ari.2003. Membangun Good Governence di Desa.Jogjakarta.IRE Press.

Geerez, C. 1972. The Interpretation of Cultures. New York. Basic Books.

Karim,Abdul Gaffar.2003. Kompleksitas Persoalan Otonomi Daerah.Jogjakarta.Pustaka Pelajar.

Koentjaraningrat. 1984. Kebudayaan Jawa. Jakarta. Balai Pustaka.

Koentjaraningrat. 1985. Beberapa Pokok Antropologi Sosial. Jakarta. Gramedia.

Petit Philip. 1975. The Concept of Structuralism, 4 Crytical Analysis. California USA. California University Press.

Pas Octivio. 1997. Levi Strauss Empu Antropology Modern. Jakarta. LkiS.
Peursen, Van, CA. 1978. Strategi Kebudayaan. Yogyakarta. Kanisius.

Strauss.Claude Levi. 1974. Structural Antropology. New York. Basic Books.

$\begin{array}{cr}\text { Wellek,Rene } & \text { dan } \\ \text { Warren.1989.Teori } & \text { Kesusastraan. } \\ \text { Jakarta.Gram edia } & \end{array}$

Widyatwati,Ken 2008. Mitos Sesaji Rewando di Gua Kreo. Hasil Penelitian Hibah Kompetitif FIB Undip

Widyatwati,Ken 2012 Mitos Labuhan Laur di Sendang Si Kucing. Hasil Penelitian Hibah Kompetitif FIB Undip

Www.jatengprov.go.id www.jatengprov.go.id www.batikplumpungan.com www.batikselotigo.com 